\title{
Considerations when investigating IncRNA function in vivo
}

Abstract Although a small number of the vast array of animal long non-coding RNAs (IncRNAs) have known effects on cellular processes examined in vitro, the extent of their contributions to normal cell processes throughout development, differentiation and disease for the most part remains less clear. Phenotypes arising from deletion of an entire genomic locus cannot be unequivocally attributed either to the loss of the IncRNA per se or to the associated loss of other overlapping DNA regulatory elements. The distinction between cis- or trans-effects is also often problematic. We discuss the advantages and challenges associated with the current techniques for studying the in vivo function of IncRNAs in the light of different models of IncRNA molecular mechanism, and reflect on the design of experiments to mutate IncRNA loci. These considerations should assist in the further investigation of these transcriptional products of the genome.

DOI: 10.7554/eLife.03058.001

\section{ANDREW R BASSETT*, ASIFA AKHTAR, DENISE P BARLOW, ADRIAN P BIRD, NEIL BROCKDORFF, DENIS DUBOULE, ANNE EPHRUSSI, ANNE C FERGUSON-SMITH, THOMAS R GINGERAS, WILFRIED HAERTY, DOUGLAS R HIGGS, ERIC A MISKA AND CHRIS P PONTING*}

*For correspondence: andrew.bassett@path.ox.ac.uk (ARB); chris.ponting@dpag.ox. ac.uk (CPP)

\section{Reviewing editor: Detlef} Weigel, Max Planck Institute for Developmental Biology, Germany

CC Copyright Bassett et al. This article is distributed under the terms of the Creative Commons Attribution License, which permits unrestricted use and redistribution provided that the original author and source are credited.
Complex transcription interwoven between and within protein-coding genes produces many thousands of long non-coding RNAs (IncRNAs) that are greater than 200 nucleotides (nt) in length but that appear to lack protein-coding potential (Djebali et al., 2012). Nevertheless, even for the earliest discovered IncRNAs, such as mammalian $H 19$, Xist or fruitfly roX, molecular effects and functional significance have proven difficult to establish (Gabory et al., 2010; Ilik et al., 2013; Sado and Brockdorff, 2013). Furthermore, no or only subtle mouse phenotypes were revealed by detailed loss-of-function studies of Malat1 or Evf-2. In contrast, mutation of Fendrr results in early lethality, and targeted replacement of $B C 1$ results in seizures for some mice (Table 1). It is not possible to accurately predict from the level or extent of its expression, or its sequence composition, whether disruption of a IncRNA locus will result in an overt phenotype. This makes loss- or gain-of-function experiments crucial to understanding the roles of IncRNAs in vivo.
Many IncRNAs are known to act as primary host transcripts for classes of small non-coding RNAs (da Rocha et alı, 2008; Royo and Cavaille, 2008). However, IncRNAs are also presumed to regulate the expression either of their neighbouring genes in cis, or of more distant genes in trans (Figure 1). The function of a IncRNA may be mediated by the gene's RNA product which can bind to proteins or to other nucleic acids thereby modulating their functions. This could act by competing with endogenous mRNAs for miRNA binding (FrancoZorrilla et al., 2007; Poliseno et al., 2010; Jeck and Sharpless, 2014), providing binding sites for small RNAs that elicit transcriptional silencing (Wierzbicki et al., 2009), or through altering protein activity (Feng et al., 2006), binding or specificity (reviewed in Guttman and Rinn, 2012). Alternatively, the act of transcription per se through a IncRNA locus could be critical because of the changes this generates in chromatin structure, modification or protein binding: in this case the resultant RNA could be an incidental by-product 
Table 1. Representative studies that have disrupted IncRNA loci in vivo (N/A—not applicable)

\begin{tabular}{|c|c|c|c|c|c|}
\hline $\begin{array}{l}\text { IncRNA } \\
\text { name }\end{array}$ & Organism & $\begin{array}{l}\text { Mutation } \\
\text { strategy }\end{array}$ & $\begin{array}{l}\text { Reported animal } \\
\text { phenotype }\end{array}$ & $\begin{array}{l}\text { RNA-based } \\
\text { rescue? }\end{array}$ & Reference \\
\hline Xist & Mus musculus & $\begin{array}{l}\sim 15 \mathrm{~kb} \text { replaced } \\
\text { with a neo expression } \\
\text { cassette }\end{array}$ & $\begin{array}{l}\text { Females inheriting } \\
\text { paternal allele were } \\
\text { embryonic lethal; } \\
\text { males fully viable }\end{array}$ & No & $\begin{array}{l}\text { (Marahrens et al., } \\
\text { 1997) }\end{array}$ \\
\hline Xist & Mus musculus & $\begin{array}{l}\text { Inversion of Exon } 1 \\
\text { to intron } 5\end{array}$ & $\begin{array}{l}\text { Embryonic lethality } \\
\text { of paternally inherited } \\
\text { allele }\end{array}$ & No & $\begin{array}{l}\text { (Senner et al., } \\
\text { 2011) }\end{array}$ \\
\hline H19 & Mus musculus & $\begin{array}{l}\text { Replacement by } \\
\text { neo cassette }\end{array}$ & $\begin{array}{l}\text { Slightly increased } \\
\text { growth }\end{array}$ & No & $\begin{array}{l}\text { (Ripoche et al., } \\
1997)\end{array}$ \\
\hline roX & $\begin{array}{l}\text { Drosophila } \\
\text { melanogaster }\end{array}$ & $\begin{array}{l}\text { Deletions of roX1 } \\
\text { or roX2 }\end{array}$ & $\begin{array}{l}\text { None, except when } \\
\text { in combination: } \\
\text { male-specific } \\
\text { reduction in viability }\end{array}$ & Yes & $\begin{array}{l}\text { (Meller and } \\
\text { Rattner, 2002) }\end{array}$ \\
\hline Kcnq1ot1 & Mus musculus & $\begin{array}{l}\text { Promoter } \\
\text { deletion }\end{array}$ & $\begin{array}{l}\text { Growth deficiency for } \\
\text { paternally inherited } \\
\text { mutation }\end{array}$ & No & $\begin{array}{l}\text { (Fitzpatrick et al., } \\
\text { 2002) }\end{array}$ \\
\hline Airn & Mus musculus & $\begin{array}{l}\text { Premature } \\
\text { transcriptional } \\
\text { termination }\end{array}$ & $\begin{array}{l}\text { Growth deficiency for } \\
\text { paternally inherited } \\
\text { mutation }\end{array}$ & No & $\begin{array}{l}\text { (Sleutels et al., } \\
\text { 2002) }\end{array}$ \\
\hline Evf2 & Mus musculus & $\begin{array}{l}\text { Premature } \\
\text { transcriptional } \\
\text { termination }\end{array}$ & None & N/A & (Bond et al., 2009) \\
\hline$B C 1$ & Mus musculus & $\begin{array}{l}\text { Replacement } \\
\text { of promoter and } \\
\text { exon by PgkNeo } \\
\text { cassette }\end{array}$ & $\begin{array}{l}\text { Vulnerable to } \\
\text { epileptic fits after } \\
\text { auditory stimulation }\end{array}$ & No & $\begin{array}{l}\text { (Zhong et al., } \\
\text { 2009) }\end{array}$ \\
\hline Neat1 & Mus musculus & $\begin{array}{l}3 \mathrm{~kb} \text { Promoter } \\
\text { and } 5^{\prime} \text { deletion }\end{array}$ & None & N/A & $\begin{array}{l}\text { (Nakagawa et al., } \\
\text { 2011) }\end{array}$ \\
\hline Tsx & Mus musculus & $\begin{array}{l}2 \mathrm{~kb} \text { Promoter } \\
\text { and exon } 1 \text { deletion }\end{array}$ & $\begin{array}{l}\text { Smaller testes and } \\
\text { less fearful (males) }\end{array}$ & No & $\begin{array}{l}\text { (Anguera et al., } \\
\text { 2011) }\end{array}$ \\
\hline Malat1 & Mus musculus & Deletion & None & N/A & $\begin{array}{l}\text { (Eissmann et al., } \\
\text { 2012) }\end{array}$ \\
\hline Malat1 & Mus musculus & $\begin{array}{l}\text { lacZ insertion and } \\
\text { premature transcriptional } \\
\text { termination }\end{array}$ & None & N/A & $\begin{array}{l}\text { (Nakagawa et al., } \\
\text { 2012) }\end{array}$ \\
\hline Malat1 & Mus musculus & $\begin{array}{l}3 \mathrm{~kb} \text { Promoter and } \\
5^{\prime} \text { deletion }\end{array}$ & None & N/A & $\begin{array}{l}\text { (Zhang et al., } \\
\text { 2012) }\end{array}$ \\
\hline Hotair & Mus musculus & Deletion & $\begin{array}{l}\text { Spine and wrist } \\
\text { malformations }\end{array}$ & No & (Li et al., 2013) \\
\hline $\begin{array}{l}\text { Hotdog } \\
\text { and Twin } \\
\text { of Hotdog }\end{array}$ & Mus musculus & $\begin{array}{l}\text { Large }(28 \mathrm{Mb}) \\
\text { translocation } \\
\text { by inversion }\end{array}$ & $\begin{array}{l}\text { Loss of Hoxd } \\
\text { expression in } \\
\text { the cecum }\end{array}$ & $\mathrm{N} / \mathrm{A}$ & $\begin{array}{l}\text { (Delpretti et al., } \\
\text { 2013) }\end{array}$ \\
\hline Fendrr & Mus musculus & $\begin{array}{l}\text { Replacement of exon } 1 \\
\text { with transcriptional stop } \\
\text { signal }\end{array}$ & $\begin{array}{l}\text { Embryonic lethal } \\
\text { around E13.75 }\end{array}$ & $\begin{array}{l}\text { Yes (majority } \\
\text { of embryos) }\end{array}$ & $\begin{array}{l}\text { (Grote et al., } \\
2013 \text { ) }\end{array}$ \\
\hline Fendrr & Mus musculus & $\begin{array}{l}\text { Locus replacement } \\
\text { with lacZ cassette }\end{array}$ & Perinatal lethality & No & $\begin{array}{l}\text { (Sauvageau } \\
\text { et al., 2013) }\end{array}$ \\
\hline Peril & Mus musculus & $\begin{array}{l}\text { Locus replacement } \\
\text { with lacZ cassette }\end{array}$ & Perinatal lethality & No & $\begin{array}{l}\text { (Sauvageau } \\
\text { et al., 2013) }\end{array}$ \\
\hline Mdgt & Mus musculus & $\begin{array}{l}\text { Locus replacement } \\
\text { with lacZ cassette }\end{array}$ & $\begin{array}{l}\text { Reduced viability } \\
\text { and reduced growth }\end{array}$ & No & $\begin{array}{l}\text { (Sauvageau } \\
\text { et al., 2013) }\end{array}$ \\
\hline $\begin{array}{l}15 \text { other } \\
\text { IncRNA } \\
\text { loci }\end{array}$ & Mus musculus & $\begin{array}{l}\text { Locus replacement } \\
\text { with lacZ cassette }\end{array}$ & None & N/A & $\begin{array}{l}\text { (Sauvageau } \\
\text { et al., 2013) }\end{array}$ \\
\hline
\end{tabular}



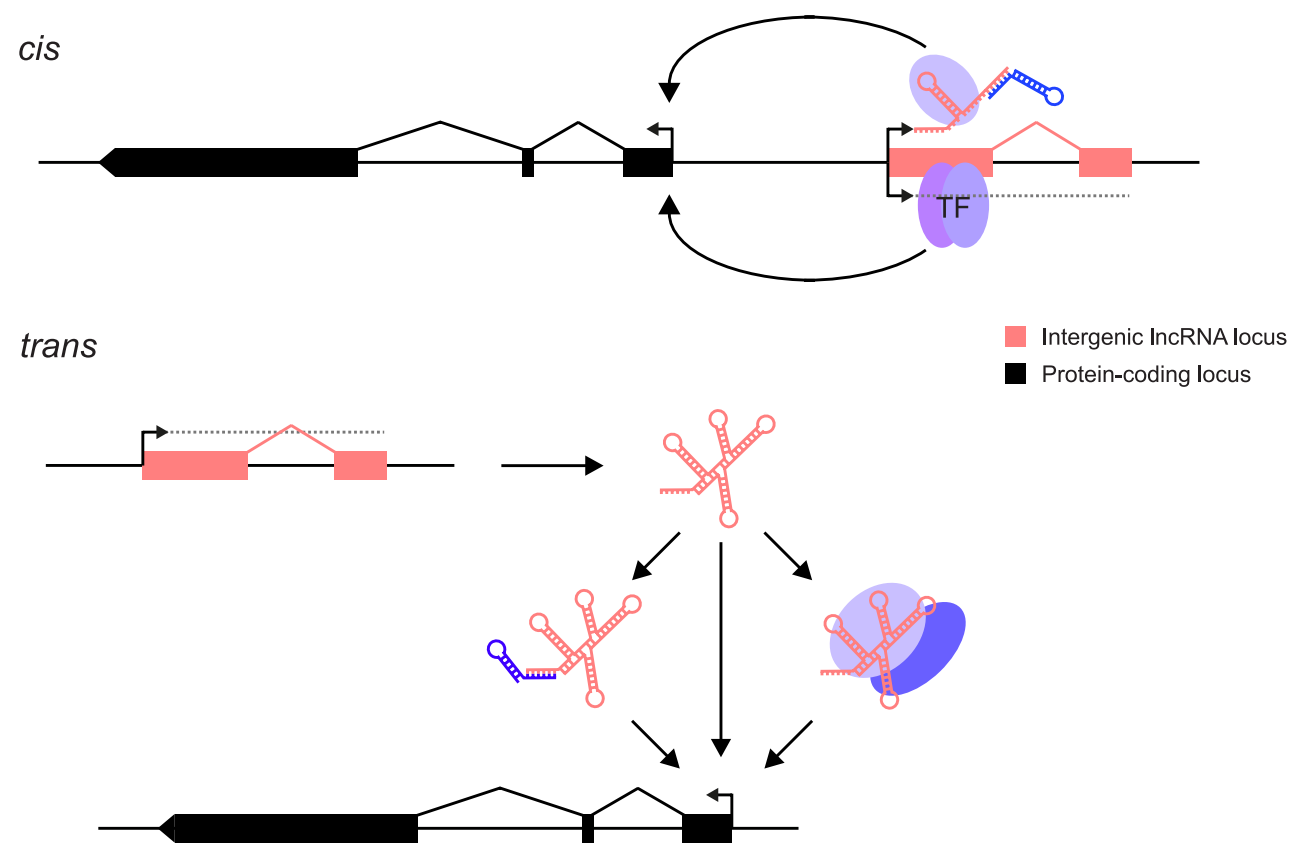

Figure 1. IncRNAs can act through cis and/or trans mechanisms. IncRNAs (pink) can act to regulate expression of their genomically neighbouring protein-coding genes (black) in cis (upper panel), or of distant protein-coding genes in trans (lower panel). In both situations, the RNA moiety itself may act through binding to cellular proteins (blue ovals) or via base-pairing with other RNAs (blue stem-loop) to modulate their function or binding. The RNA may also directly bind double-stranded DNA in trans (Grote et al., 2013) or in cis (Senner et al., 2011). The IncRNA locus (pink) may also encompass transcription factor binding sites (TF) that regulate the transcription of neighbouring genes. This effect may either be entirely independent of the IncRNA, or the binding of transcription factors may be affected positively or negatively by the act of transcription through the IncRNA locus. In this case, the mature RNA product would be incidental.

DOI: 10.7554/eLife.03058.003

(Petruk et al., 2006; Latos et al., 2012; Marquardt et al., 2014). In these latter cases, any technique intended to dissect mechanism must alter the act and extent of transcription rather than change RNA levels. This multiplicity of IncRNA functional mechanisms means that a toolkit of experimental strategies to dissect their modes of action will need to be added to those currently employed for investigating proteincoding genes. Protein-coding genes have been shown to contribute greatly to biological function, which is not yet the case for IncRNA loci, rendering their rigorous investigation particularly important.

Analysis of IncRNA localisation both on a tissue and subcellular level by techniques such as fluorescent in situ hybridisation (FISH, Chakraborty et al., 2012) can give important insights into the cell types that are important for their function, and in which subcellular compartment they act. Understanding the mechanism of action of IncRNAs often relies on identification of interacting proteins or nucleic acids by RNA-protein (e.g., crosslinking immunoprecipitation, CLIP, Huppertz et al., 2014), RNA-RNA (e.g., crosslinking analysis of synthetic hybrids, CLASH, Helwak et al., 2013) or RNA-DNA (e.g., CHART, Simon et al., 2011; Vance and Ponting, 2014 and ChIRP, Chu et al., 2011) interaction assays. However, due to the nature of the RNA molecule, many assays are prone to non-specific binding, and it is critical to ensure that appropriate controls are performed (Brockdorff, 2013). Several of these techniques have therefore been designed to identify direct interactors by crosslinking, and subsequent use of denaturing conditions to remove non-specific interactions. These techniques are clearly important in determining the mechanism of action of IncRNAs, and are critical to guide experimental genetic knockout design. However, an understanding of the functional importance of IncRNAs in the context of the whole organism still relies on manipulating their expression by genetic modification, overexpression or knockdown strategies, and analysis of the resulting phenotypes.

The earliest studied IncRNAs were those associated with imprinting, such as Airn and H19, or $\mathrm{X}$ chromosome regulation, such as Xist or roX1/2 (Table 1). In these cases, IncRNA expression was initially linked genetically to a known phenotype, 
and cell line models accurately reflected the in vivo models (Hao et al., 1993; Keniry et al., 2012; Latos et al., 2012; Helwak et al., 2013; Huppertz et al., 2014). These results highlight that the early models of IncRNAs involved in imprinting and $X$ chromosomal dosage compensation could act as paradigms for the study of IncRNAs today (Kohtz, 2014). In the absence of a priori phenotypic associations, some IncRNAs have been chosen for study on the basis of their tissue restricted patterns of expression, sequence conservation, or cellular localisation. Others, such as MALAT1 (whose level of expression is associated with metastasis) have been selected on the basis of their suggested association with disease. Neat 1 and Malat1 (also known as Neat2) are linked loci that produce highly expressed IncRNAs whose sequences are well conserved across diverse mammals and which have specific nuclear localisations (Chu et al., 2011). In cells, Neat1 was shown to be essential for nuclear paraspeckle assembly and maintenance (Clemson et al., 2009; Sasaki and Hirose, 2009; Sunwoo et al., 2009; Mao et al., 2011a, 2011b; Zhang et al., 2012) and Malat1/Neat2 binds to the Polycomb 2 (PC2) protein which is required for activating growthcontrol genes (Vance and Ponting, 2014). Nevertheless, in vivo disruption of either of these IncRNA loci results in viable and fertile mouse models (Table 1).

Confirmation or rejection of IncRNA functionality requires experimental evidence that clearly separates the role of the genomic locus from the role of its RNA products. Here we recommend experimental techniques that achieve this separation whilst minimising disruption of the DNA sequence. Furthermore, we propose some considerations that may assist in interpreting phenotypes arising from mutation of a IncRNA or IncRNA locus (Box 1).

\section{In vivo, loss-of-function strategies}

Different genetic loss-of-function strategies can be employed in vivo to study the function of IncRNAs (Figure 2). Prioritisation of strategy should depend on the IncRNA's known biology, including its localisation to one or more of the cytoplasm, nucleus or chromatin. In one study, the majority of human IncRNAs were enriched in the cytoplasm (van Heesch et al., 2014) and these may associate with ribosomes and, contrary to expectations, some may be translated (Guttman et al., 2013; Kim et al., 2014; Wilhelm et al., 2014). Nuclear IncRNAs, particularly those that are chromatin-associated, could act as cis-acting transcriptional regulators, whereas cytoplasmic or nucleoplasmic IncRNAs might be predicted to function in trans; by contrast, some nucleoplasmic IncRNAs may of course be non-functional products of transcription.

Depletion of protein-coding transcripts is often achieved using RNAi-based techniques, which supply double-stranded RNA that is able to trigger post-transcriptional destabilisation of the mature mRNA and inhibit translation, predominantly in the cytoplasm. Although the presence of active RNAi factors in human cell nuclei has been proposed (Gagnon et al., 2014) the extent to which exclusively nuclear IncRNAs can be knocked down remains unclear. Whilst useful for studies of many trans-acting IncRNAs, RNAi-based knockdown acts post-transcriptionally, and therefore does not block the act of transcription, precluding analyses of IncRNAs which may produce their effects via this mechanism.

Another experimental approach is to genetically manipulate the IncRNA locus. When inserting transcriptional terminator sequences care must be taken to control for changes in spacing between DNA regulatory elements and to take account of regulatory elements that may be inadvertently inserted, such as promoters of resistance genes, since these may be able to drive expression of neighbouring genes or divert activities from nearby enhancers. Insertion of exogenous sequences can induce phenotypes (Steshina et al., 2006). Even single loxP sites can attract germline methylation that might potentially repress flanking regulatory elements (Rassoulzadegan et al., 2002). Extra controls are thus needed to identify possible gain-of-function effects arising from inserted sequences, such as reporters or selection cassettes. The advent of programmable nucleases (Kim and Kim, 2014) provides opportunities to investigate these possibilities. Transcriptional terminator sequences can vary in their efficacy depending on the genomic context into which they are inserted, which can cause termination to be highly inefficient. For example, a sequence that efficiently terminates transcription in multiple contexts in Airn, failed to do so when inserted close to a CpG island (Latos et al., 2012).

Other approaches include deletion of the fulllength IncRNA locus or its promoter sequence, mutation of putative functional domains or targeted interruption between the promoter and the RNA sequence through an engineered inversion (Figure 2; Table 1). Whilst useful, such strategies may not always be successful. Promoter inversion, for instance, may not always abrogate transcription, because of the bidirectionality of 


\section{Box 1. Considerations when interpreting phenotypes resulting from IncRNA mutation}

\section{General Considerations}

- The design of functional experiments should be guided by the essential RNA biology of the chosen IncRNA locus: its proximity to protein-coding genes, its chromatin signatures, stability, copy number, full-length transcript models and tissue expression profiles. If it shares a bidirectional promoter then minimise interference with the adjacent locus when designing targeting strategies. If more abundant and stable, with promoter-like chromatin marks at its transcriptional start site, then consider whether the IncRNA acts in trans in an RNA dependent manner.

- Consider all available transcript, regulatory element and evolutionary evidence when designing mutations.

- Consider whether, contrary to initial expectations, the IncRNA encodes protein or, as for $\mathrm{H} 19$, harbours a miRNA.

- Choice of loss-of-function strategy and prediction of whether the IncRNA acts in cis or in trans should be informed by its cytoplasmic, nuclear or chromatin localisation. If found in the cytoplasm, consider whether it is, in fact, translated. If chromatin-associated consider whether it acts in cis. In contrast, if cytoplasmic or nucleoplasmic, consider whether it is trans-acting.

- Choose cells for functional experiments in which the IncRNA is relatively highly expressed, certainly at greater than one molecule per cell.

- Minimise genomic sequence disruptions when investigating IncRNA or IncRNA locus function. Use control manipulations to distinguish disruptions influencing flanking genes from those influencing the IncRNA.

- Investigate each locus using multiple complementary strategies, for example introduction of minimal targeted DNA deletions, inversions or disruptions and, separately, of transcriptional truncation cassettes. Consider using controls for genetic manipulations of IncRNA loci: inverting the truncation cassette where possible, using a mutated truncation cassette, using a different type of truncation cassette, and using different sites to truncate the IncRNA. It is important to remove any selection cassettes and to consider the influence of reporter genes and loxP sites on the locus. Fully describe the mutated locus, including whether the selection cassette is retained.
- Assay biological replicates separately. Embryonic stem (ES) or induced pluripotent (iPS) cells frequently vary in their differentiation kinetics, especially after undergoing gene targeting and selection, and mouse embryos, particularly early implantation stage mouse embryos, show considerable variation in developmental timing. Similarly, cancer cell lines are inherently genetically unstable. This variability makes it essential to study multiple clones of cells or independently derived mutants to ensure that the effects observed are due to the mutation of interest, and not dependent on other effects of the genetic background. This is especially important when the phenotypic effects are subtle.

Assessment of evidence for IncRNA functionality

- Consider the evidence for each of the many known transcriptional or post-transcriptional, nuclear or cytoplasmic, cis or trans, RNA-dependent or -independent mechanisms of IncRNAs.

- Employ RNAi-based techniques principally when investigating cytoplasmic RNAs and post-transcriptional RNAdependent mechanisms. If using RNAi, the knockdown effect on the cytoplasmic and nuclear compartment should be determined separately. An alternative is to use antisense DNA oligos to induce an RNase $\mathrm{H}$ activity in the nucleus.

- Only claim that a phenotype is caused by alteration of a trans-acting IncRNA transcript when it is successfully and repeatedly rescued upon expression of the IncRNA from an independent transgene.

- Take advantage of carefully controlled biochemical approaches when assessing the potential function of a IncRNA.

Publications and reporting

- Assess and report objectively all evidence for or against RNA sequence-dependent function or transcriptiondependent (RNA sequence-independent) function.

- Report phenotypes precisely. Commonly, gene knockouts kill embryos at critical periods for example, implantation, gastrulation, $12.5 \mathrm{dpc}$ when the cardiovascular system become essential, and at birth when lungs and many other systems become essential. In general the maternal organs rescue many organ defects of the embryo. For ES cells, phenotypes affecting pluripotency need to be defined and should be considered with caution due to the inherent instability of this state.

- Explicitly caution when evidence for RNA-dependent vs-independent function, or trans- vs cis-acting function, is not clear-cut. promoters (Wu and Sharp, 2013), and promoter deletion may also disrupt the expression level of protein-coding transcripts with which IncRNAs share a bidirectional promoter. In all of these cases, it is important to minimise the removal or reorganisation of regulatory factor binding sites or other regulatory elements within the DNA, and to control for the addition of novel binding sites. For example, it should be borne in mind that many IncRNAs initiate within enhancers 


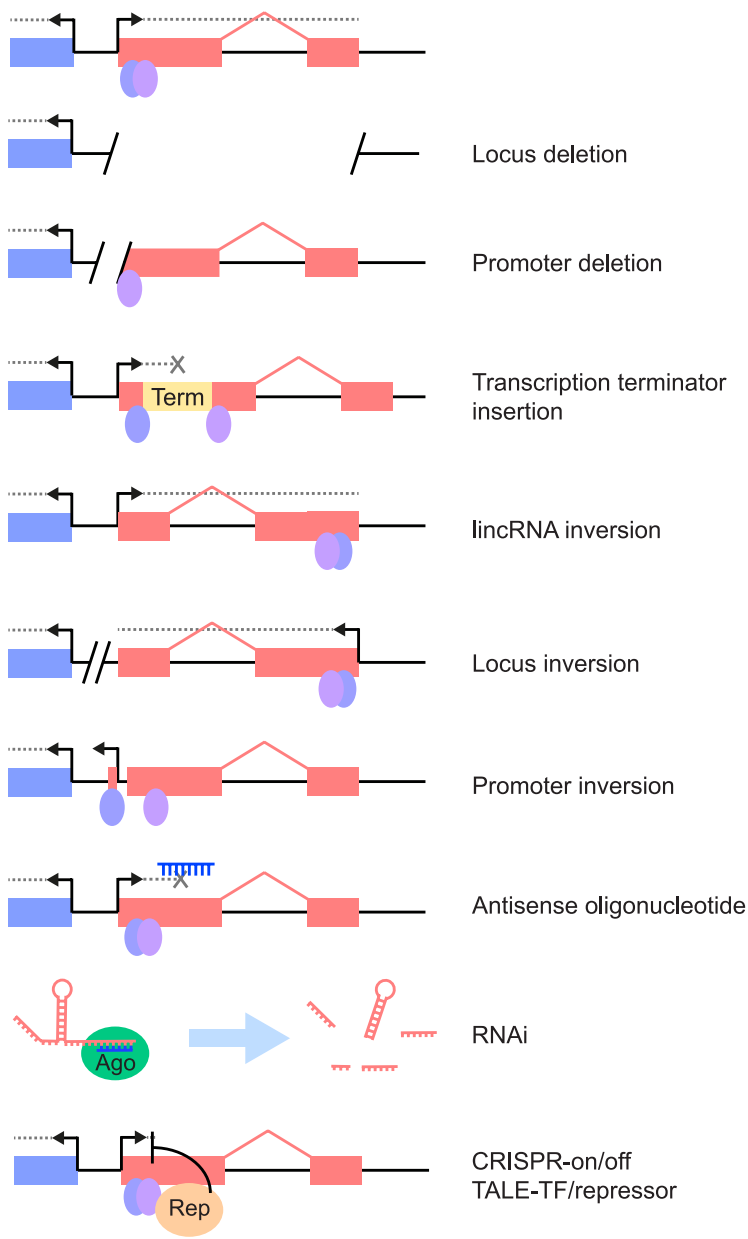

\begin{tabular}{|c|c|c|}
\hline $\begin{array}{l}\text { Prevents } \\
\text { transcription }\end{array}$ & $\begin{array}{l}\text { Disrupts underlying } \\
\text { DNA elements }\end{array}$ & $\begin{array}{c}\text { Stable } \\
\text { transgenics }\end{array}$ \\
\hline Yes & $\begin{array}{l}\text { Removes } \\
\text { completely }\end{array}$ & Yes \\
\hline Yes & Removes some & Yes \\
\hline Reduces & Alters spacing & Yes \\
\hline No & Alters spacing & Yes \\
\hline No & $\begin{array}{l}\text { Alters genomic } \\
\text { context }\end{array}$ & Yes \\
\hline Yes & Alters spacing & Yes \\
\hline Reduces & No & No \\
\hline No & No & Yes \\
\hline Reduces & No & Yes \\
\hline
\end{tabular}

Transcription factors

IncRNA exons

Neighbouring protein coding gene

Figure 2. Different strategies for analysis of IncRNA loss-of-function. Strategies that have been used to alter IncRNA function are described pictorially, with the wild type situation on the top-most line. The IncRNA locus is indicated in pink, neighbouring protein-coding gene in blue, transcription factor binding sites within it by blue and purple ovals, transcriptional terminator sequences in yellow ('Term') and the process of transcription by grey dotted lines. Antisense oligonucleotides are able to bind to nascent RNA transcripts and trigger RNase $\mathrm{H}$ mediated degradation of the transcript in the nucleus. RNAi is elicited by short RNA species that bind to argonaute proteins (Ago, green oval) within the cell. This complex recognises complementary IncRNA molecules in the cytoplasm, and triggers their destabilisation by the endogenous cellular machinery. The CRISPR and TALE systems use designer DNA binding factors to recruit repressor or activator domains (orange oval) to the IncRNA to affect transcriptional initiation. The effects of each strategy upon the process of transcription and presence of underlying DNA elements such as transcription factor binding sites are indicated. The possibility of generating stable transgenic animals to investigate phenotypes throughout development is also noted.

DOI: 10.7554/eLife.03058.004

(Marques et al., 2013) and in these cases disruption of the IncRNA promoter could also cause unintended changes in gene expression. In the case of transcription terminators, to ensure effects are due to changes in RNA rather than DNA, inversions of the terminator sequence or a variety of different terminators can be used. In the experimental design it is also important to consider alternatively spliced transcripts and additional transcriptional start sites to ensure full abrogation of IncRNA expression.

Antisense oligonucleotides might provide an alternative technique for analysis of IncRNA function. They are thought to act by forming a DNA/ RNA hybrid with the nascent RNA transcript, and triggering RNase $\mathrm{H}$-dependent degradation of the RNA in the nucleus (Figure 2). This reduces the level of the RNA before the mature transcript 
is produced, but the nature and extent of off-target effects are not fully understood and may be substantial (Sahu et al., 2007). Also, it is not possible to generate stable transgenic lines, which restricts analysis to cell lines or to systems where the oligonucleotides can be supplied by injection. Other approaches to disrupting IncRNA function use morpholino antisense oligos targeting e.g. splice sites (Ulitsky et al., 2011), or locked nucleic acid antisense oligonucleotides (Sarma et al., 2010).

Recent developments in rational design of DNA binding factors using transcription activator-like effector (TALE) proteins or the clustered regularly interspersed palindromic repeats (CRISPR) system have enabled recruitment of transcriptional activation (Cheng et al., 2013) or repression domains (Cong et al., 2012; Gilbert et al., 2013) to defined sites within the genome to modulate transcription, or to directly interfere with the passage of the RNA polymerase. These techniques could be used to modulate the rate of transcriptional initiation or elongation of the IncRNA (Figure 2), but care must be taken to control for direct effects of these factors on the transcription of neighbouring genes.

\section{Separating RNA- from DNA-sequence dependent effects}

Deletion of a IncRNA genomic locus does not cleanly separate a role of the IncRNA per se from a role of other functional elements contained within the underlying DNA. Such elements might be irrelevant to the IncRNA's function, yet critical to the normal function of a neighbouring proteincoding gene. Eighteen mouse knockout lines were recently described in which genomic regions containing intergenic IncRNA loci (21.6 kb mean size, $4.8 \mathrm{~kb}-49.7 \mathrm{~kb}$ range) were deleted and replaced by a lacZ reporter cassette (Sauvageau et al., 2013). For 13 of these lines no overt phenotypes were reported. In contrast, strong phenotypes from 5 knockout lines were observed: $\mathrm{Peril}^{-/-}$or Fendrr ${ }^{-/-}$mice have reduced viability; $\mathrm{Mdgt}^{-/-}$and linc-Pint ${ }^{-/-}$mice show growth defects; and linc-Brn $1 b^{-/-}$mice exhibit abnormal cortical anatomy. The authors conclude that these developmental disorders generated by DNA deletions demonstrate the critical roles that IncRNAs play in vivo (Sauvageau et al., 2013).

While this may be the correct interpretation, the strong phenotypes observed in these lines may derive from the engineered deletion of cisregulatory DNA elements lying within these large DNA deletions that are critical for the normal functions of proximal protein-coding genes. For instance Fendrr is $1.4 \mathrm{~kb}$ from Foxf1, and Mdgt starts only $84 \mathrm{bp}$ from the $5^{\prime}$ exon of Hoxd 1 and terminates close to Hoxd3 (Figure 3). Consistent with this notion, data from the ENCODE project indicate that the genomic region deleted in $\mathrm{Mdgt}^{-/-}$lines contains binding sites for several transcription factors and chromatin regulatory proteins (Figure 3). Whilst the authors detected no global change of neighbouring protein-coding gene expression as assessed by limited RNAseq of tissues, it is still possible that altered cell type or developmental stage specific expression of these genes escaped detection. LncRNAs are often transcribed in a highly restricted cell population and a global, high-throughput analysis of even the full embryo may not have been informative. Ultimately, the best evidence for RNA-dependent IncRNA function derives from loss-of-function, followed by complementation approaches, as for example described in Grote et al. (2013).

This issue is also relevant for other IncRNAs transcribed from within Hox gene clusters. In the case of Hotair (Rinn et al., 2007), a several kb large deletion of the entire Hotair genomic DNA in vivo induces a subtle morphological phenotype in the spine, which was interpreted as a gain-of-function of Hoxd genes in trans (Li et al., 2013). However, Hotair is embedded in the HoxC gene cluster and topological modifications or re-arrangements in such a dense series of transcription units are likely to modify the expression of neighbouring genes. Further insights have been acquired by removing the entire HoxC locus, including both the IncRNA locus and flanking genes (Suemori and Noguchi, 2000; Schorderet and Duboule, 2011). Even when multiple alleles are available, as for Hotair, IncRNA function remains difficult to evaluate.

\section{Expression specificity and allelic series}

Deletion of the mouse Hotair IncRNA also induced a subtle developmental phenotype in the wrist (Li et al., 2013). However, because murine Hotair transcripts were not detected in developing forelimb buds (Schorderet and Duboule, 2011) it remains possible that this phenotype develops from a lack of Hotair RNAs during subsequent stages of wrist development. This possibility could only be assessed by further analysis of the expression pattern of this IncRNA. The systematic introduction of a reporter cassette into IncRNAs (Sauvageau et al., 2013) can help solve this problem, provided the difference between the stability of the reporter staining and the half-life of the RNA is kept in mind, in particular for small and dynamic cell populations (Zakany et al., 2001). 

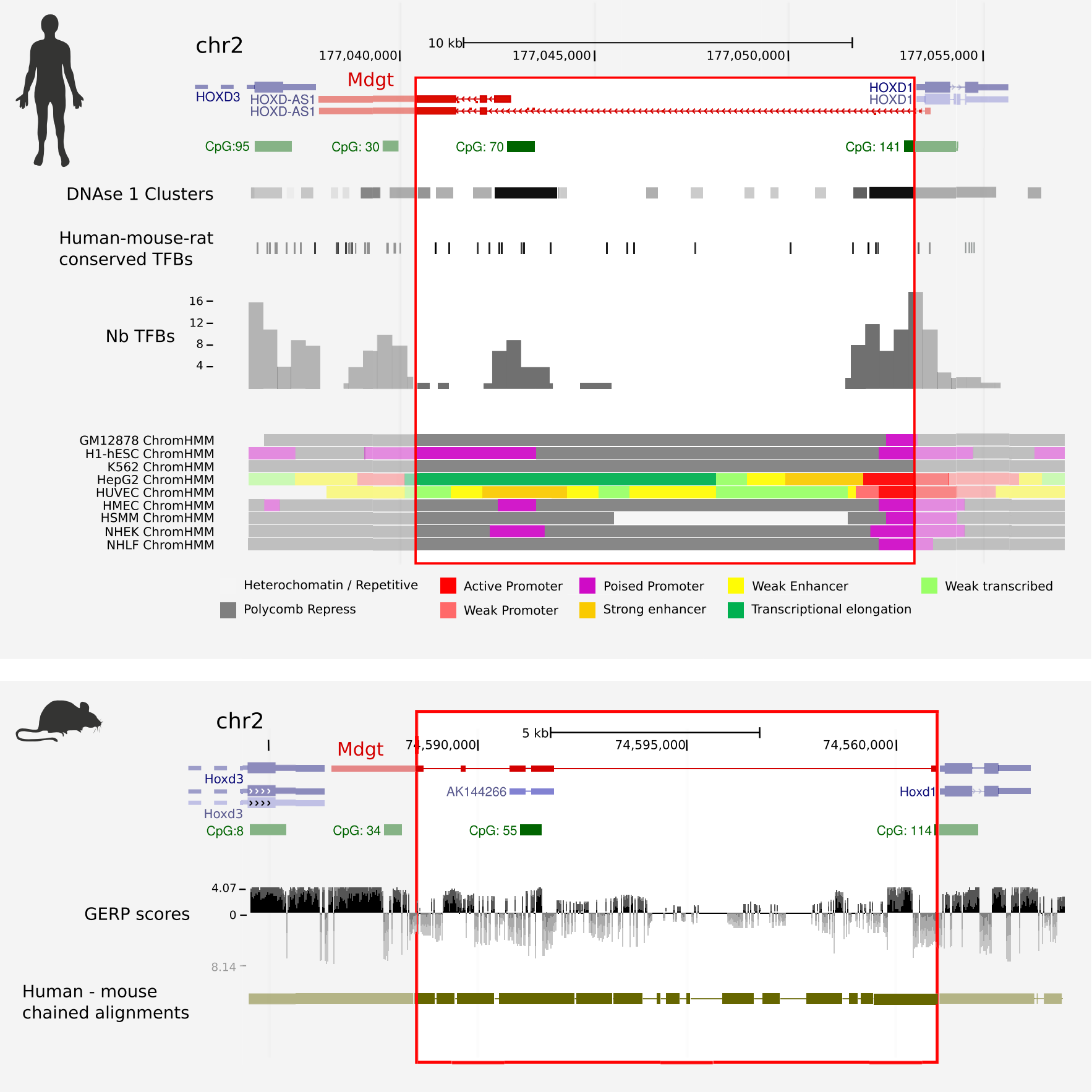

Figure 3. Human and mouse ENCODE data indicate that $\mathrm{Mdgt}^{-/-}$lines contain deletions of conserved binding sites for transcription factors and chromatin regulatory proteins. The engineered deletion in mouse, and its equivalent sequence in human, are indicated by red rectangles, and spans $85 \%$ (12.4 kb of $14.7 \mathrm{~kb}$ ) of intergenic sequence between mouse Hoxd1 and Hoxd3. Mdgt, virtually shares its start site with Hoxd1, a gene expressed with exquisite specificities in only a few cell populations during early development (Zakany et al., 2001). Predicted transcription factor binding sites (TFBs) that are conserved in human, mouse and rat are shown against the human genome (Consortium, 2012; Ernst and Kellis, 2012). Numbers of experimentally-determined TFBs per genomic interval are shown in the histogram, and clusters of DNase 1 hypersensitivity sites, are also shown aligned against the human locus. Predicted CpG islands acquired from the UCSC Genome Browser are shown in green, and chained human-mouse alignments are shown in olive green. Evolutionary conservation (GERP) scores are indicated below the mouse locus.

DOI: 10.7554/eLife.03058.005

As for protein-coding genes, an exhaustive description of functional traits associated with a particular IncRNA cannot be achieved by using a single mutant allele, hence allelic series are necessary. As indicated above, the nature of the alleles required to assess the function of a given 
IncRNA depends upon its genomic location and its expression specificity during development and adulthood. This can be quite challenging, as exemplified by the bidirectional Hotdog and Twin of hotdog IncRNAs: even though these RNAs are located hundreds of $\mathrm{kb}$ distant from the HoxD gene cluster in the middle of a gene desert, their shared start site physically interacts with Hoxd genes as part of a general regulatory structure. In this case, a cis-effect could in principle be evaluated by separating the IncRNA loci from the HoxD cluster via a large inversion with a breakpoint in-between. It turns out, however, that this inversion globally disrupts the regulation of HoxD by displacing long-range acting enhancers along with the IncRNA loci, making interpretation difficult (Delpretti et al., 2013).

\section{Discrepancies between different strategies}

The IncRNA Fendrr has been studied using two independent strategies: genetic deletion (Sauvageau et al., 2013) and transcriptional terminator insertion (Grote et al., 2013). Whilst both studies describe a lethal phenotype, highlighting the potential importance of this IncRNA in development, the outcomes differ. Genetic deletion results in lung maturation and mesenchymal differentiation defects (Sauvageau et al., 2013), whilst terminator insertion leads to heart and body wall defects and to effects on the expression of the neighbouring Foxf1 gene (Grote et al., 2013). Importantly, the defects caused by terminator insertion were rescued by a transgene containing a single wild type copy of the Fendrr IncRNA locus (without its functional Foxf1 neighbour); this strongly implicates deletion of the RNA product, rather than its genomic DNA, as causing the observed phenotypes (Grote et al., 2013). Transgene rescue experiments are thus crucial for establishing RNA-dependent IncRNA function. An earlier successful illustration of this principle was the rescue of developmental defects in zebrafish by coinjection of spliced RNA for each of two IncRNAs, cyrano and megamind, whose precursor RNAs had been knocked down using morpholino antisense oligos (Ulitsky et al., 2011). However, regulatory sequences necessary for the transcription of the IncRNA itself should ideally be included in the rescue construct so as to maintain physiological levels of expression. This, added to the length of IncRNAs that can sometimes reach several hundred kb, may represent a challenge for a transgenic approach.

Substantial differences have also been observed between RNAi-mediated knockdown and transcriptional terminator insertion at the Evf-2 IncRNA locus (Feng et al., 2006; Bond et al., 2009; Berghoff et al., 2013; Kohtz, 2014). This IncRNA is transcribed across an enhancer element between the D/x5 and D/x6 genes, and initial studies in cell culture using RNAi suggested a model whereby Evf-2 was important for activation of D/x5/6 (Feng et al., 2006). However, transcriptional terminator insertion in mice has shown the opposite effect on expression of D/x5/6 (Bond et al., 2009) and causes specific changes in DNA methylation at the enhancer. Importantly these changes can be rescued by Evf-2 expression from a separate transgene, implying that they are dependent on the IncRNA itself (Berghoff et al., 2013).

Similarly to this example, knockdown of lincRNA-p21 by RNAi originally suggested a trans-acting mechanism, in which the IncRNA was involved in recruiting protein complexes to chromatin (Huarte et al., 2010). Nevertheless, subsequent studies where the promoter of the IncRNA was deleted or its transcription was blocked by antisense oligonucleotides have highlighted a different role, as this IncRNA regulates the adjacent p21 gene in cis, without having trans-acting effects (Dimitrova et al., 2014). Whilst both studies analysed by RNAseq the effect of IncRNA depletion on global gene expression in mouse embryonic fibroblasts, the two sets of differentially expressed genes did not overlap significantly. When analysing IncRNA function, it is thus important to consider multiple loss-of-function strategies that address multiple mechanisms of action.

The potential confounding effects of techniques used to separate DNA- from RNA-dependent function are further exemplified by studies of the Drosophila bxd IncRNA, which is expressed from within the HOX cluster, adjacent to the Ultrabithorax (Ubx) gene. Its expression is highly specific and occurs in the same broad region of the embryo as the Ubx gene, although notably never within the same cell (Petruk et al., 2006). Studies of bxd loss-of-function using different techniques have yielded conflicting interpretations. It has long been known that small deletions within this IncRNA cause dramatic effects on expression of the neighbouring Ubx gene (Lewis, 1978), resulting in homoeotic transformations. Indeed, certain allelic combinations are able to generate a four-winged fly. More recent studies of the same deletions suggest that the act of transcription of this IncRNA represses Ubx in cis by altering protein binding to the Ubx promoter (Petruk et al., 2006). In contrast, it was reported that inversion of the bxd promoter, driving transcription in the wrong direction whilst maintaining genomic composition, results in very minor effects on Ubx 
expression, and then only later in development (Pease et al., 2013). Also, a deletion removing the promoter induced a $\mathrm{Cdx}$-like gain of function of Ubx (Sipos et al., 2007). Clearly, correct interpretation of such loss-of-function experiments, at such complex loci, requires careful consideration of potentially confounding factors.

Contrasting results of different experiments may also arise because of a IncRNA's involvement in different mechanisms in different cellular contexts. For example, in embryonic cells, transcription of Airn silences the adjacent lgf2r gene (Latos et al., 2012), whereas in extraembryonic tissues it acts more distally by recruiting the histone methyltransferase G9a to imprinted genes (Nagano et al., 2008).

\section{The end of the beginning: a maturing IncRNA field}

The study of IncRNAs is still in its infancy, and the biochemical and genetic techniques used to address the true significance and mechanisms of action of this class of RNA have only recently been developed or adapted from those used for investigating protein-coding genes. Such techniques must therefore be used with caution and with appropriate controls (Brockdorff, 2013; Riley and Steitz, 2013). From the examples described above, it is apparent that the optimal strategy with which to study a IncRNA's loss of function depends both on the mechanism by which it acts, in particular in a cis or trans configuration, and the regulatory sequences present within its locus. We suggest that early lessons learnt from paradigm repressor IncRNAs, such as Xist, and imprinted IncRNAs such as Airn or Kcnq1ot1, should guide the design of experiments on more recently identified IncRNAs. We have attempted to distil these lessons into the proposed considerations in Box 1. Introduction of the multiple alleles that will be necessary to adequately dissect IncRNA in vivo function will be greatly aided by recent advances in genome engineering using designer site-specific nucleases such as CRISPR/Cas9 and TALENs. The introduction of fast acute loss-of-function systems for IncRNAs, for example those that insert a sequence-specific ribonuclease site whose nuclease is under drug inducible control, would also greatly facilitate IncRNA investigation.

The trans function of a IncRNA may be investigated using locus deletion, promoter deletion, inversions, transcriptional termination or RNAi. Where possible, these strategies should be combined with genetic rescue experiments, where the IncRNA is expressed from an independent transgene inserted at a location distinct from the IncRNA locus. This strategy separates RNA-dependent effects from those arising from the manipulation of the underlying DNA. Rescue experiments using expression of the IncRNA from an independent transgene are only possible for trans-acting IncRNAs where the RNA moiety itself and not the act of transcription is critical for function.

The cis function of a IncRNA may be investigated using a combination of several alleles, such as insertion of transcriptional terminators, promoter deletions and inversions. Several alleles are likely to be required to separate IncRNA-dependent from other effects and, as controls, to reveal artefacts of genetic engineering. Engineered inversions can also be used to separate the IncRNA locus from its potential neighbouring target gene to investigate its roles in cis. Use of site-specific recombinases, such as the phiC31/attP system (Bateman et al., 2006; Zhu et al., 2014) as 'landing sites' or for recombination mediated cassette exchange, will greatly enhance our ability to generate such allelic series. For example, the IncRNA locus may be deleted and replaced by a recombinase 'landing site' into which different constructs can be introduced to investigate phenotype rescue.

In summary, if IncRNA biologists are to resolve the true in vivo functions of these numerous and enigmatic transcripts, then the strengths and weaknesses of available techniques will need to be acknowledged. Resolution will no doubt derive from the careful and comprehensive genetic dissection of individual loci using multiple alleles. The field of IncRNA biology would benefit greatly from the development of additional approaches that are effective in distinguishing effects mediated by IncRNAs as molecular species from their effect on gene regulatory elements with which IncRNA loci are interleaved across the mammalian genome.

\section{Acknowledgements}

$A B$ \& CPP: the European Research Council (DARCGENs, project number 249869) and the Medical Research Council. AA: Max Planck Institute. DD: the European Research Council (SystemsHox.ch) and the Swiss National Research Foundation. APB: the Wellcome Trust. DPB: Austrian Academy of Sciences and the Austrian Science Fund FWF F4302-B09. AE: the European Molecular Biology Laboratory. AFS: The Wellcome Trust and MRC. DRH: the Medical Research Council. EAM: Cancer Research UK. TRG: NHGRI U54 HG007004-2. 
Andrew R Bassett is in the MRC Functional Genomics Unit, Department of Physiology, Anatomy and Genetics, University of Oxford, Oxford, United Kingdom.

Present address: Sir William Dunn School of Pathology, University of Oxford, Oxford, United Kingdom Asifa Akhtar is in the Department of Chromatin Regulation, Max-Planck-Institut für Immunbiologie und Epigenetik, Freiburg im Breisgau, Germany

Denise P Barlow is in the CeMM, Research Center for Molecular Medicine of the Austrian Academy of Sciences, Vienna, Austria

Adrian P Bird is in the Wellcome Trust Centre for Cell Biology, University of Edinburgh, Edinburgh, United Kingdom

Neil Brockdorff is in the Department of Biochemistry, University of Oxford, Oxford, United Kingdom

Denis Duboule is in the School of Life Sciences, Ecole Polytechnique Fédérale Lausanne, Lausanne, Switzerland; Department of Genetics and Evolution, Université de Genève, Geneva, Switzerland

Anne Ephrussi is in the Developmental Biology Unit, European Molecular Biology Laboratory, Heidelberg, Germany

(iD) http://orcid.org/0000-0002-5061-4620

Anne C Ferguson-Smith is in the Department of Genetics, University of Cambridge, Cambridge, United Kingdom

Thomas R Gingeras is in the Functional Genomics Group, Cold Spring Harbor Laboratory, Cold Spring Harbor, United States

Wilfried Haerty is in the MRC Functional Genomics Unit, Department of Physiology, Anatomy and Genetics, University of Oxford, Oxford, United Kingdom

Douglas R Higgs is in the MRC Molecular Haematology Unit, Weatherall Institute of Molecular Medicine, Oxford, United Kingdom

Eric A Miska is in the Wellcome Trust Cancer Research UK Gurdon Institute, University of Cambridge, Cambridge, United Kingdom; Department of Genetics, University of Cambridge, Cambridge, United Kingdom

Chris P Ponting is in the MRC Functional Genomics Unit, Department of Physiology, Anatomy and Genetics, University of Oxford, Oxford, United Kingdom; Wellcome Trust Sanger Institute, Cambridge, United Kingdom (iD http://orcid.org/0000-0003-0202-7816

\section{Author contributions}

ARB, CPP, Conception and design, Drafting or revising the article; $A A, D P B, A P B, N B, D D, A E, A C F-S, T R G$, $W H, D R H, E A M$, Drafting or revising the article

Competing interests: CPP: Senior Editor, eLife. AA: Reviewing Editor, eLife. ACF-S: Reviewing Editor, eLife. TRG: Reviewing Editor, eLife. The other authors declare that no competing interests exist.
Received 09 April 2014

Accepted 28 July 2014

Published 14 August 2014

\section{Funding}

\begin{tabular}{|c|c|c|}
\hline Funder & $\begin{array}{l}\text { Grant } \\
\text { reference } \\
\text { number }\end{array}$ & Author \\
\hline $\begin{array}{l}\text { European } \\
\text { Research } \\
\text { Council }\end{array}$ & $\begin{array}{l}\text { DARCGENS } \\
249869\end{array}$ & $\begin{array}{l}\text { Andrew R Bassett, } \\
\text { Chris P Ponting }\end{array}$ \\
\hline $\begin{array}{l}\text { Medical } \\
\text { Research } \\
\text { Council }\end{array}$ & & $\begin{array}{l}\text { Anne C Ferguson- } \\
\text { Smith, Wilfried } \\
\text { Haerty, Douglas R } \\
\text { Higgs, Chris P } \\
\text { Ponting }\end{array}$ \\
\hline $\begin{array}{l}\text { Max-Planck- } \\
\text { Gesellschaft }\end{array}$ & & Asifa Akhtar \\
\hline $\begin{array}{l}\text { European } \\
\text { Research } \\
\text { Council }\end{array}$ & SystemsHOX.ch & Denis Duboule \\
\hline $\begin{array}{l}\text { Swiss National } \\
\text { Science } \\
\text { Foundation }\end{array}$ & & Denis Duboule \\
\hline Wellcome Trust & & $\begin{array}{l}\text { Adrian P Bird, } \\
\text { Anne C Ferguson- } \\
\text { Smith }\end{array}$ \\
\hline $\begin{array}{l}\text { Austrian } \\
\text { Academy of } \\
\text { Sciences }\end{array}$ & & Denise P Barlow \\
\hline $\begin{array}{l}\text { Austrian } \\
\text { Science Fund }\end{array}$ & FWF F4302-B09 & Denise P Barlow \\
\hline $\begin{array}{l}\text { European } \\
\text { Molecular } \\
\text { Biology } \\
\text { Laboratory }\end{array}$ & & Anne Ephrussi \\
\hline $\begin{array}{l}\text { Cancer Research } \\
\text { UK }\end{array}$ & & Eric A Miska \\
\hline $\begin{array}{l}\text { National Human } \\
\text { Genome Research } \\
\text { Institute }\end{array}$ & U54 HG007004-2 & Thomas R Gin \\
\hline
\end{tabular}

The funders had no role in study design, data collection and interpretation, or the decision to submit the work for publication.

\section{Additional files}

Major dataset

The following previously published dataset was used:

\begin{tabular}{lccl}
\hline & & & $\begin{array}{l}\text { Database, } \\
\text { license, and }\end{array}$ \\
Author(s) & $\begin{array}{l}\text { Dataset } \\
\text { title }\end{array}$ & $\begin{array}{l}\text { Dataset ID } \\
\text { accessibility } \\
\text { and/or URL information }\end{array}$ \\
\hline Encode & 2012 ENCODE - https:// & Freely \\
Project & Encyclo- & genome. & available \\
Consortium & pedia of & ucsc.edu/ & at ENCODE \\
& DNA & ENCODE/ & Data \\
& elements & & Coordination \\
& & & Center (DCC).
\end{tabular}




\section{References}

Anguera MC, Ma W, Clift D, Namekawa S, Kelleher RJ III, Lee JT. 2011. Tsx produces a long noncoding RNA and has general functions in the germline, stem cells, and brain. PLOS Genetics 7:e1002248. doi: 10.1371/ journal.pgen.1002248.

Bateman JR, Lee AM, Wu CT. 2006. Site-specific transformation of Drosophila via phiC31 integrasemediated cassette exchange. Genetics 173:769-777. doi: 10.1534/genetics.106.056945.

Berghoff EG, Clark MF, Chen S, Cajigas I, Leib DE, Kohtz JD. 2013. Evf2 (Dlx6as) IncRNA regulates ultraconserved enhancer methylation and the differential transcriptional control of adjacent genes. Development 140:4407-4416. doi: 10.1242/dev.099390. Bond AM, Vangompel MJ, Sametsky EA, Clark MF, Savage JC, Disterhoft JF, Kohtz JD. 2009. Balanced gene regulation by an embryonic brain ncRNA is critical for adult hippocampal GABA circuitry. Nature Neuroscience 12:1020-1027. doi: 10.1038/nn.2371. Brockdorff N. 2013. Noncoding RNA and Polycomb recruitment. RNA 19:429-442. doi: 10.1261/ rna.037598.112.

Chakraborty D, Kappei D, Theis M, Nitzsche A, Ding L, Paszkowski-Rogacz M, Surendranath V, Berger N, Schulz H, Saar K, et al. 2012. Combined RNAi and localization for functionally dissecting long noncoding RNAs. Nature Methods 9:360-362. doi: 10.1038/ nmeth.1894.

Cheng AW, Wang H, Yang H, Shi L, Katz Y, Theunissen TW, Rangarajan S, Shivalila CS, Dadon DB, Jaenisch R. 2013. Multiplexed activation of endogenous genes by CRISPR-on, an RNA-guided transcriptional activator system. Cell Research 23:1163-1171. doi: 10.1038/ cr.2013.122.

Chu C, Qu K, Zhong FL, Artandi SE, Chang HY. 2011. Genomic maps of long noncoding RNA occupancy reveal principles of RNA-chromatin interactions. Molecular Cell 44:667-678. doi: 10.1016/j.molcel.2011.08.027.

Clemson CM, Hutchinson JN, Sara SA, Ensminger AW Fox AH, Chess A, Lawrence JB. 2009. An architectural role for a nuclear noncoding RNA: NEAT1 RNA is essential for the structure of paraspeckles. Molecular Cell 33:717-726. doi: 10.1016/j.molcel.2009.01.026. Cong L, Zhou R, Kuo YC, Cunniff M, Zhang F. 2012. Comprehensive interrogation of natural TALE DNAbinding modules and transcriptional repressor domains. Nature Communications 3:968. doi: 10.1038/ ncomms1962.

Consortium EP. 2012. An integrated encyclopedia of DNA elements in the human genome. Nature 489:57-74. doi: 10.1038/nature11247.

da Rocha ST, Edwards CA, Ito M, Ogata T, Ferguson-Smith AC. 2008. Genomic imprinting at the mammalian Dlk1-Dio3 domain. Trends in Genetics 24:306-316. doi: 10.1016/j.tig.2008.03.011.

Delpretti S, Montavon T, Leleu M, Joye E, Tzika A, Milinkovitch M, Duboule D. 2013. Multiple enhancers regulate Hoxd genes and the Hotdog LncRNA during cecum budding. Cell Reports 5:137-150. doi: 10.1016/j.celrep.2013.09.002. Dimitrova N, Zamudio JR, Jong RM, Soukup D, Resnick R, Sarma K, Ward AJ, Raj A, Lee JT, Sharp PA, et al. 2014. LincRNA-p21 activates p21 in cis to promote polycomb target gene expression and to enforce the G1/S checkpoint. Molecular Cell 54:777-790. doi: 10.1016/j.molcel.2014.04.025.
Djebali S, Davis CA, Merkel A, Dobin A, Lassmann T, Mortazavi A, Tanzer A, Lagarde J, Lin W, Schlesinger F, et al. 2012. Landscape of transcription in human cells. Nature 489:101-108. doi: 10.1038/nature11233.

Eissmann M, Gutschner T, Hammerle M, Gunther S, Caudron-Herger M, Gross M, Schirmacher P, Rippe K, Braun T, Zornig M, et al. 2012. Loss of the abundant nuclear non-coding RNA MALAT1 is compatible with life and development. RNA Biology 9:1076-1087. doi: 10.4161/rna.21089.

Ernst J, Kellis M. 2012. ChromHMM: automating chromatin-state discovery and characterization. Nature Methods 9:215-216. doi: 10.1038/nmeth.1906.

Feng J, Bi C, Clark BS, Mady R, Shah P, Kohtz JD. 2006. The Evf-2 noncoding RNA is transcribed from the Dlx-5/6 ultraconserved region and functions as a Dlx-2 transcriptional coactivator. Genes \& Development 20:1470-1484. doi: 10.1101/gad.1416106.

Fitzpatrick GV, Soloway PD, Higgins MJ. 2002.

Regional loss of imprinting and growth deficiency in mice with a targeted deletion of KvDMR1. Nature Genetics 32:426-431. doi: 10.1038/ng988.

Franco-Zorrilla JM, Valli A, Todesco M, Mateos I, Puga MI, Rubio-Somoza I, Leyva A, Weigel D, Garcia JA, Paz-Ares J. 2007. Target mimicry provides a new mechanism for regulation of microRNA activity. Nature Genetics 39:1033-1037. doi: 10.1038/ng2079.

Gabory A, Jammes H, Dandolo L. 2010. The H19 locus: role of an imprinted non-coding RNA in growth and development. BioEssays 32:473-480. doi: 10.1002/ bies.200900170.

Gagnon KT, Li L, Chu Y, Janowski BA, Corey DR. 2014. RNAi factors are present and active in human cell nuclei. Cell Reports 6:211-221. doi: 10.1016/j. celrep.2013.12.013.

Gilbert LA, Larson MH, Morsut L, Liu Z, Brar GA, Torres SE, Stern-Ginossar N, Brandman O, Whitehead EH, Doudna JA, et al. 2013. CRISPRmediated modular RNA-guided regulation of transcription in eukaryotes. Cell 154:442-451. doi: 10.1016/j.cell.2013.06.044.

Grote P, Wittler L, Hendrix D, Koch F, Wahrisch S, Beisaw A, Macura K, Blass G, Kellis M, Werber M, et al. 2013. The tissue-specific IncRNA Fendrr is an essential regulator of heart and body wall development in the mouse. Developmental Cell 24:206-214. doi: 10.1016/j. devcel.2012.12.012.

Guttman M, Rinn JL. 2012. Modular regulatory principles of large non-coding RNAs. Nature 482:339-346. doi: 10.1038/nature10887. Guttman M, Russell P, Ingolia NT, Weissman JS, Lander ES. 2013. Ribosome profiling provides evidence that large noncoding RNAs do not encode proteins. Cell 154:240-251. doi: 10.1016/j.cell.2013.06.009. Hao Y, Crenshaw T, Moulton T, Newcomb E, Tycko B. 1993. Tumour-suppressor activity of H19 RNA. Nature 365:764-767. doi: 10.1038/365764a0.

Helwak A, Kudla G, Dudnakova T, Tollervey D. 2013. Mapping the human miRNA interactome by CLASH reveals frequent noncanonical binding. Cell 153:654-665. doi: 10.1016/j.cell.2013.03.043. Huarte M, Guttman M, Feldser D, Garber M, Koziol MJ, Kenzelmann-Broz D, Khalil AM, Zuk O, Amit I, Rabani M, et al. 2010. A large intergenic noncoding RNA induced by $\mathrm{p} 53$ mediates global gene repression in the p53 response. Cell 142:409-419. doi: 10.1016/j. cell.2010.06.040. 
Huppertz I, Attig J, D'Ambrogio A, Easton LE, Sibley CR, Sugimoto Y, Tajnik M, Konig J, Ule J. 2014. iCLIP: protein-RNA interactions at nucleotide resolution. Methods 65:274-287. doi: 10.1016/j.ymeth. 2013.10.011.

Ilik IA, Quinn JJ, Georgiev P, Tavares-Cadete F, Maticzka D, Toscano S, Wan Y, Spitale RC, Luscombe N Backofen $\mathrm{R}$, et al. 2013. Tandem stem-loops in roX RNAs act together to mediate $\mathrm{X}$ chromosome dosage compensation in Drosophila. Molecular Cell 51:156-173. doi: 10.1016/j.molcel.2013.07.001.

Jeck WR, Sharpless NE. 2014. Detecting and characterizing circular RNAs. Nature Biotechnology 32:453-461. doi: 10.1038/nbt.2890.

Keniry A, Oxley D, Monnier P, Kyba M, Dandolo L, Smits G, Reik W. 2012. The H19 lincRNA is a developmental reservoir of miR-675 that suppresses growth and Igf1r. Nature Cell Biology 14:659-665. doi: 10.1038/ncb2521.

Kim H, Kim JS. 2014. A guide to genome engineering with programmable nucleases. Nature Reviews Genetics 15:321-334. doi: 10.1038/nrg3686.

Kim MS, Pinto SM, Getnet D, Nirujogi RS, Manda SS, Chaerkady R, Madugundu AK, Kelkar DS, Isserlin R, Jain S, et al. 2014. A draft map of the human proteome. Nature 509:575-581. doi: 10.1038/nature13302. Kohtz JD. 2014. Long non-coding RNAs learn the importance of being in vivo. Frontiers in Genetics 5:45. doi: 10.3389/fgene.2014.00045.

Latos PA, Pauler FM, Koerner MV, Senergin HB, Hudson QJ, Stocsits RR, Allhoff W, Stricker SH, Klement RM, Warczok KE, et al. 2012. Airn transcriptional overlap, but not its IncRNA products, induces imprinted Igf2r silencing. Science 338:1469-1472. doi: 10.1126/ science.1228110.

Lewis EB. 1978. A gene complex controlling segmentation in Drosophila. Nature 276:565-570. doi: 10.1038/276565a0.

Li L, Liu B, Wapinski OL, Tsai MC, Qu K, Zhang J, Carlson JC, Lin M, Fang F, Gupta RA, et al. 2013. Targeted disruption of Hotair leads to homeotic transformation and gene derepression. Cell Reports 5:3-12. doi: 10.1016/j.celrep.2013.09.003.

Mao YS, Sunwoo H, Zhang B, Spector DL. 2011a. Direct visualization of the co-transcriptional assembly of a nuclear body by noncoding RNAs. Nature Cell Biology 13:95-101. doi: 10.1038/ncb2140.

Mao YS, Zhang B, Spector DL. 2011b. Biogenesis and function of nuclear bodies. Trends in Genetics 27:295-306. doi: 10.1016/j.tig.2011.05.006.

Marahrens Y, Panning B, Dausman J, Strauss W, Jaenisch R. 1997. Xist-deficient mice are defective in dosage compensation but not spermatogenesis. Genes \& Development 11:156-166. doi: 10.1101/gad.11.2.156. Marquardt S, Raitskin O, Wu Z, Liu F, Sun Q, Dean C. 2014. Functional consequences of splicing of the antisense transcript COOLAIR on FLC transcription. Molecular Cell 54:156-165. doi: 10.1016/j. molcel.2014.03.026.

Marques AC, Hughes J, Graham B, Kowalczyk MS, Higgs DR, Ponting CP. 2013. Chromatin signatures at transcriptional start sites separate two equally populated yet distinct classes of intergenic long noncoding RNAs. Genome Biology 14:R131. doi: 10.1186/gb-2013-14-11-r131.

Meller VH, Rattner BP. 2002. The roX genes encode redundant male-specific lethal transcripts required for targeting of the MSL complex. EMBO Journal 21:1084-1091. doi: 10.1093/emboj/21.5.1084. Nagano T, Mitchell JA, Sanz LA, Pauler FM, Ferguson-Smith AC, Feil R, Fraser P. 2008. The air noncoding RNA epigenetically silences transcription by targeting G9a to chromatin. Science 322:1717-1720. doi: 10.1126/science.1163802.

Nakagawa S, Ip JY, Shioi G, Tripathi V, Zong X, Hirose T, Prasanth KV. 2012. Malat1 is not an essential component of nuclear speckles in mice. RNA 18:1487-1499. doi: 10.1261/rna.033217.112. Nakagawa S, Naganuma T, Shioi G, Hirose T. 2011. Paraspeckles are subpopulation-specific nuclear bodies that are not essential in mice. Journal of Cell Biology 193:31-39. doi: 10.1083/jcb.201011110.

Pease B, Borges AC, Bender W. 2013. Noncoding RNAs of the ultrabithorax domain of the Drosophila Bithorax complex. Genetics 195:1253-1264.

doi: 10.1534/genetics.113.155036.

Petruk S, Sedkov Y, Riley KM, Hodgson J, Schweisguth F, Hirose S, Jaynes JB, Brock HW, Mazo A. 2006. Transcription of bxd noncoding RNAs promoted by trithorax represses $\mathrm{Ubx}$ in cis by transcriptional interference. Cell 127:1209-1221. doi: 10.1016/j.cell.2006.10.039.

Poliseno L, Salmena L, Zhang J, Carver B, Haveman WJ, Pandolfi PP. 2010. A coding-independent function of gene and pseudogene mRNAs regulates tumour biology. Nature 465:1033-1038. doi: 10.1038/nature09144.

Rassoulzadegan M, Magliano M, Cuzin F. 2002.

Transvection effects involving DNA methylation during meiosis in the mouse. EMBO Journal 21:440-450. doi: 10.1093/emboj/21.3.440.

Riley KJ, Steitz JA. 2013. The "Observer Effect" in genome-wide surveys of protein-RNA interactions. Molecular Cell 49:601-604. doi: 10.1016/j. molcel.2013.01.030.

Rinn JL, Kertesz M, Wang JK, Squazzo SL, Xu X, Brugmann SA, Goodnough LH, Helms JA, Farnham PJ, Segal $E$, et al. 2007. Functional demarcation of active and silent chromatin domains in human HOX loci by noncoding RNAs. Cell 129:1311-1323. doi: 10.1016/j. cell.2007.05.022.

Ripoche MA, Kress C, Poirier F, Dandolo L. 1997. Deletion of the $\mathrm{H} 19$ transcription unit reveals the existence of a putative imprinting control element. Genes \& Development 11:1596-1604. doi: 10.1101/ gad.11.12.1596.

Royo H, Cavaille J. 2008. Non-coding RNAs in imprinted gene clusters. Biology of the Cell 100:149-166. doi: 10.1042/BC20070126.

Sado T, Brockdorff N. 2013. Advances in understanding chromosome silencing by the long non-coding RNA Xist. Philosophical Transactions of the Royal Society of London Series B, Biological sciences 368:20110325. doi: 10.1098/rstb.2011.0325.

Sahu NK, Shilakari G, Nayak A, Kohli DV. 2007. Antisense technology: a selective tool for gene expression regulation and gene targeting. Current Pharmaceutical Biotechnology 8:291-304. doi: 10.2174/138920107782109985.

Sarma K, Levasseur P, Aristarkhov A, Lee JT. 2010. Locked nucleic acids (LNAs) reveal sequence requirements and kinetics of Xist RNA localization to the $\mathrm{X}$ chromosome. Proceedings of the National Academy of Sciences of USA 107:22196-22201. doi: 10.1073/pnas.1009785107. 
Sasaki YT, Hirose T. 2009. How to build a paraspeckle. Genome Biology 10:227. doi: 10.1186/gb-2009-10-7-227. Sauvageau M, Goff LA, Lodato S, Bonev B, Groff AF, Gerhardinger C, Sanchez-Gomez DB, Hacisuleyman E, Li E, Spence M, et al. 2013. Multiple knockout mouse models reveal lincRNAs are required for life and brain development. eLife 2:e01749. doi: 10.7554/eLife.01749. Schorderet P, Duboule D. 2011. Structural and functional differences in the long non-coding RNA hotair in mouse and human. PLOS Genetics 7:e1002071. doi: 10.1371/journal.pgen.1002071. Senner CE, Nesterova TB, Norton S, Dewchand H, Godwin J, Mak W, Brockdorff N. 2011. Disruption of a conserved region of Xist exon 1 impairs Xist RNA localisation and $X$-linked gene silencing during random and imprinted $\mathrm{X}$ chromosome inactivation. Development 138:1541-1550. doi: 10.1242/dev.056812.

Simon MD, Wang Cl, Kharchenko PV, West JA, Chapman BA, Alekseyenko AA, Borowsky ML, Kuroda MI, Kingston RE. 2011. The genomic binding sites of a noncoding RNA. Proceedings of the National Academy of Sciences of USA 108:20497-20502. doi: 10.1073/pnas.1113536108.

Sipos L, Kozma G, Molnar E, Bender W. 2007. In situ dissection of a Polycomb response element in Drosophila melanogaster. Proceedings of the National Academy of Sciences of USA 104:12416-12421. doi: 10.1073/ pnas.0703144104.

Sleutels F, Zwart R, Barlow DP. 2002. The non-coding Air RNA is required for silencing autosomal imprinted genes. Nature 415:810-813. doi: 10.1038/415810a. Steshina EY, Carr MS, Glick EA, Yevtodiyenko A, Appelbe OK, Schmidt JV. 2006. Loss of imprinting at the Dlk1-Gtl2 locus caused by insertional mutagenesis in the GtI2 5' region. BMC Genetics 7:44. doi: 10.1186/1471-2156-7-44.

Suemori H, Noguchi S. 2000. Hox C cluster genes are dispensable for overall body plan of mouse embryonic development. Developmental biology 220:333-342. doi: 10.1006/dbio.2000.9651.

Sunwoo H, Dinger ME, Wilusz JE, Amaral PP, Mattick JS, Spector DL. 2009. MEN epsilon/beta nuclear-retained non-coding RNAs are up-regulated upon muscle differentiation and are essential components of paraspeckles. Genome Research 19:347-359. doi: 10.1101/gr.087775.108.
Ulitsky I, Shkumatava A, Jan CH, Sive H, Bartel DP. 2011. Conserved function of lincRNAs in vertebrate embryonic development despite rapid sequence evolution. Cell 147:1537-1550. doi: 10.1016/j.cell.2011.11.055. van Heesch S, van Iterson M, Jacobi J, Boymans S, Essers PB, de Bruijn E, Hao W, Macinnes AW, Cuppen E, Simonis M. 2014. Extensive localization of long noncoding RNAs to the cytosol and mono- and polyribosomal complexes. Genome Biology 15:R6. doi: 10.1186/ gb-2014-15-1-r6.

Vance KW, Ponting CP. 2014. Transcriptional regulatory functions of nuclear long noncoding RNAs. Trends in Genetics 30:348-355. doi: 10.1016/j.tig.2014.06.001. Wierzbicki AT, Ream TS, Haag JR, Pikaard CS. 2009. RNA polymerase $\mathrm{V}$ transcription guides ARGONAUTE4 to chromatin. Nature Genetics 41:630-634. doi: 10.1038/ ng.365.

Wilhelm M, Schlegl J, Hahne H, Moghaddas Gholami A, Lieberenz M, Savitski MM, Ziegler E, Butzmann L, Gessulat S, Marx H, et al. 2014. Mass-spectrometrybased draft of the human proteome. Nature 509:582-587. doi: 10.1038/nature13319.

Wu X, Sharp PA. 2013. Divergent transcription: a driving force for new gene origination? Cell 155:990-996. doi: 10.1016/j.cell.2013.10.048.

Zakany J, Kmita M, Alarcon P, de la Pompa JL, Duboule D. 2001. Localized and transient transcription of Hox genes suggests a link between patterning and the segmentation clock. Cell 106:207-217. doi: 10.1016/S0092-8674(01)00436-6.

Zhang B, Arun G, Mao YS, Lazar Z, Hung G, Bhattacharjee G, Xiao X, Booth CJ, Wu J, Zhang C, et al. 2012. The IncRNA Malat1 is dispensable for mouse development but its transcription plays a cis-regulatory role in the adult. Cell Reports 2:111-123. doi: 10.1016/j.celrep.2012.06.003.

Zhong J, Chuang SC, Bianchi R, Zhao W, Lee H, Fenton AA, Wong RK, Tiedge H. 2009. BC1 regulation of metabotropic glutamate receptor-mediated neuronal excitability. Journal of Neuroscience 29:9977-9986. doi: 10.1523/JNEUROSCI.3893-08.2009.

Zhu F, Gamboa M, Farruggio AP, Hippenmeyer $S$, Tasic B, Schule B, Chen-Tsai Y, Calos MP. 2014. DICE, an efficient system for iterative genomic editing in human pluripotent stem cells. Nucleic Acids Research 42:e34. doi: 10.1093/nar/gkt1290. 